\title{
The value of public agricultural and food knowledge during pandemics
}

\author{
Leland Glenna ${ }^{1}$
}

Accepted: 23 April 2020 / Published online: 13 May 2020

(c) Springer Nature B.V. 2020

Covid-19 is an exemplary case of a public bad. Although the disease threatens some demographic categories more than others, the pandemic ultimately threatens the entire public. Therefore, knowledge about the causes, consequences, and strategies to mitigate the pandemic is a public good that will benefit us all. Because such public knowledge is unlikely to be profitable, there is little incentive for private firms to invest in the research. It is therefore up to governments to support university research to generate such knowledge.

Publicly funded, public-goods agriculture and food research is necessary for understanding and preventing pandemics, like Covid-19, because pandemics often originate in the agriculture and food system. Private goods are things that people must buy, whereas public goods are available to everyone. Potential zoonotic viruses are ubiquitous, but they will not jump from one species to another without the right conditions. The destruction of wildlife habitat and the crowding of different species into marketplaces are two conditions that facilitate species jumping (Bodin 2020). Knowledge about how the agricultural and food system fosters the creation and spread of zoonotic viruses is a public good because all people benefit from knowledge that could protect them from infection.

There is evidence that the 2003 SARS virus and the current Covid-19 pandemic passed through intermediary species after originating in bats. SARS moved from bats to people through civets, and Covid-19 through pangolins. Because pangolins are endangered species, they are poached and smuggled into China where their meat and scales are believed to provide health benefits. The butchering of these animals, when people interact with the animal fluids most

This article is part of the Topical Collection: Agriculture, Food \& Covid-19.

Leland Glenna

1lg13@psu.edu

1 University Park, USA directly, provides the optimal conditions for a virus that has mutated in just the right way to cross the species barrier (Breiman 2020). Zoonotic diseases like Covid-19 thus reveal distressing dimensions of the global agriculture and food system that are not adequately understood or regulated through private commerce.

Since colleges of agriculture at United States land-grant universities have thousands of social and biophysical scientists who study natural resource use and the agriculture and food system, these agricultural colleges are well positioned to explain the complex social and biophysical dynamics that promote the emergence and spread of the diseases, including habitat loss, the exploitation and maltreatment of animals, and inequality, injustice, and dangerous and unhygienic working conditions. All of these issues have public dimensions that leave them outside the purview of food markets in most countries. Unfortunately, public funding for agriculture and food research has stagnated and even declined in the United States and other industrial nations over the past five decades, and agriculture and food research has increasingly been directed at generating private goods.

In 1973, nearly $70 \%$ of research at all US universities came from the federal government. In 2018, the federal government provided only $53 \%$. Universities themselves funded more than $25 \%$ of the research at their own institutions in 2018, compared to less than $10 \%$ in 1973. This information signals that universities must generate their own revenues to keep pace with research needs. Universities often do this by expanding endowments, attracting gifts from private firms, and encouraging faculty to privatize their activities by patenting and licensing their research findings (NSF 2020). University patenting activities have increased substantially over the past two decades (Glenna 2017). In the agriculture and food sector, government funding for research and development declined in real dollars between 2005 and 2015, while private investment increased sharply (Clancy et al. 2016). This means that the private sector is likely driving 
the research agenda and that private goods are emphasized over public goods (Glenna 2017).

The value of public goods is illustrated in the 2013 book Me Medicine vs. We Medicine. We Medicine refers to a range of public-health interventions, including vaccinations and food-safety regulations, that are meant to promote the health of all members of society. By contrast, Me Medicine focuses on research directed at developing products that individuals can purchase to address personal health issues. Dickenson (2013) describes how Me Medicine is currently emphasized over We Medicine. Limitations with Me Medicine become clear during a pandemic because a public bad threatens everyone and, therefore, requires a public response.

The trend toward increasingly relying on the private sector to fund university research that is likely to generate private goods is problematic at any time, but its inadequacy becomes even starker during a pandemic. The public sector needs to provide robust funding for agriculture and food research that is directed at producing public knowledge about the social and biophysical causes of pandemics and strategies for reducing their widespread impacts.

\section{References}

Bodin, Madeline. 2020. Coronaviruses Often Start in Animals Here's How Those Diseases Can Jump to Humans. Discover
Magazine, April 2. https://www.discovermagazine.com/health/ coronaviruses-often-start-in-animals-heres-how-those-diseasescan-jump-to. Accessed 14 Apr 2020.

Breiman, Robert F. 2020. The Covid-19 culprit is us, not pangolins. CNN Opinion, 27 March. https://www.cnn.com/2020/03/27/ opinions/pangolin-coronavirus-pandemic-breiman/index.html. Accessed 14 Apr 2020.

Clancy, Matthew, Keith Fuglie, and Paul Heisey. 2016. U.S. Agricultural R\&D in an Era of Falling Public Funding. Amber Waves, November 10.

Dickenson, Donna. 2013. Me Medicine vs. We Medicine: Reclaiming Biotechnology for the Common Good. New York, NY: Columbia University Press.

Glenna, Leland L. 2017. The Purpose-Driven University: The Role of University Research in the Era of Science Commercialization. Agriculture and Human Values 34 (4): 1021-1031.

National Science Foundation (NSF). 2020. Science \& Engineering Indicators-2020. Alexandria, VA: National Center for Science and Engineering Statistics.

Publisher's Note Springer Nature remains neutral with regard to jurisdictional claims in published maps and institutional affiliations.

Leland Glenna is a Professor of Rural Sociology and Science, Technology, and Society in the Agricultural Economics, Sociology, and Education Department at the Pennsylvania State University. His research interests are in the areas of the sociology of agriculture and food, the social studies of science and technology, and environmental sociology. 